\title{
Analisis Prinsip Ketiga Littlewood dalam Teori Fungsi Variabel Ril
}

\author{
Wahidah Alwi \\ Program Studi Matematika,Wahidah.alwi@uin-alauddin.ac.id \\ Ishak \\ Mahasiswa Program Studi Matematika, ishakr97@gmail.com
}

\begin{abstract}
ABSTRAK, Penelitian ini membahas tentang prinsip ketiga dari tiga prinsip littlewood dalam teori fungsi variabel ril yaitu hampir setiap barisan fungsi terukur yang konvergen adalah konvergen seragam. Penelitian ini bertujuan menganalisis prinsip tersebut dengan mengkaji kekonvergenan barisan fungsi terukur. pembahasan dalam tulisan ini berisi kekonntinuan dalam fungsi terukur dan kekonvergenan barisan fungsi terukur serta kaitannya dengan kekonvergenan seragam. Lebih jauh dalam tulisan ini akan ditunjukkan suatu sifat yang menyatakan terdapatnya kekonvergenan seragam dalam barisan fungsi terukur konvergen.
\end{abstract}

Kata Kunci: barisan konvergen, fungsi kontinu, fungsi terukur

\section{PENDAHULUAN}

Tiga prinsip Littlewood banyak dijelaskan dalam literatur yang membahas tentang teori fungsi variabel ril. prinsip ketiga littlewood menyatakan bahwa hampir setiap barisan fungsi terukur yang konvergen adalah konvergen seragam. Selanjutnya untuk fungsi terukur memiliki beberapa sifat, salah satunya adalah kekontinuan fungsi.

Fungsi $f$ dikatakan terukur apabila $f$ terdefinisi dengan daerah asal terukur. Fungsi terukur dapat dilihat pada berbagai fungsi yang tidak asing seperti fungsi tangga dan fungsi kontinu dengan daeah asal terukur

Kekontinuan suatu fungsi secara umum diilustrasikan dengan fungsi yang grafiknya tidak terputus disuatu titik dalam interval yang diberikan. Misalkan $f$ terdefinisi pada $[a, b], f$ dikatakan kontinu pada $[a, b]$ jika $f$ kontinu disetiap titik pada interval $[a, b]$. Sebagai hal yang cukup mendasar dalam bidang matematika, penelitian mengenai fungsi tidak hanya terbatas dalam dalam ruang yang sempit akan tetapi dikaji hingga konvergensi barisannya ketika menuju tak hingga.

Salah satu kekonvergenan dalam barisan fungsi adalah kekonvergenan seragam. Kekonvergenan ini memiliki kemampuan untuk mempertahankan kekontinuan fungsi. Kekonvergenan seragam menunjukkan bahwa barisan fungsi kontinu yang konvergen akan konvergen kesuatu fungsi yang kontinu.

Berkaitan dengan hal-hal tersebut diatas, tulisan ini bertujuan membahas mengenai kekonvergenan seragam dari barisan fungsi terukur guna menganalisis prinsip ketiga Littlewood dalam teori fungsi variable ril.

\section{TINJAUANPUSTAKA}

\section{Fungsi terukur}

Secara umum suatu fungsi dikatakan terukur dengan melihat daerah asal fungsi tersebut yang terukur. Namun ketika diperhatikan lebih jauh terdapat kondisi yang harus dipenuhi agar suatu fungsi dikatakan terukur.

\section{Definisi 1:}

Misalkan $(X, \mathfrak{U})$ adalah ruang terukur dan misalkan $D \in \mathfrak{A}$. Fungsi $f$ bernilai ril diperluas yang terdefinisi pada $D$ dikatakan terukur $\mathfrak{A}$ pada $D$ jika memenuhi kondisi $\{x \in D: f(x) \leq \alpha\} \in$ $\mathfrak{U}$ yang berarti $f^{-1}([-\infty, \alpha]) \in \mathfrak{U}$ untuk setiap $\alpha \in \mathbb{R}$.

Selanjutnya, jika $(X, \mathfrak{U})=\left(\mathbb{R}, \mathfrak{M}_{L}\right), \quad D \in \mathfrak{M}_{L}$ dan $f$ terukur $\mathfrak{M}_{L}$ pada $D$ maka $f$ dikatakan terukur Lebesgue.

\section{Proposisi 2:}

Andaikan $f$ fungsi ril dengan daerah asal himpunan terukur, maka keempat pernyataan berikut ekuivalen.

a. $\forall \alpha \in \mathbb{R},\{x \mid f(x)>\alpha\}$ himpunan terukur

b. $\forall \alpha \in \mathbb{R},\{x \mid f(x) \geq \alpha\}$ himpunan terukur

c. $\forall \alpha \in \mathbb{R},\{x \mid f(x)<\alpha\}$ himpunan terukur

d. $\forall \alpha \in \mathbb{R},\{x \mid f(x) \leq \alpha\}$ himpunan terukur

Akibat keempat pernyataan diatas yaitu 
e. $\forall \alpha \in \mathbb{R},\{x \mid f(x)=\alpha\}$ himpunan terukur

Operasi dalam fungsi terukur hampir sama dengan operasi fungsi pada umumnya. Misalkan $c \in \mathbb{R}$, kemudian $f$ dan $g$ terdefinisi pada domain terukur, maka $c f, f+g, f o g, \frac{g}{f}$ merupakan fungsi terukur.

\section{Kekontinuan Dalam Fungsi Terukur}

Suatu fungsi yang terukur dalam penjelasan sebelumnya dapat diketahui dengan melihat daerah asalnya. Jika daerah asal fungsi tersebut terukur maka fungsi tersebut terukur. Pernyataan ini juga berlaku pada fungsi terukur kontinu sebagai berikut.

\section{Teorema 3:}

Fungsi kontinu yang didefinisikan pada himpunan terukur adalah fungsi terukur.

\section{Bukti:}

Misalkan $f: D \rightarrow \mathbb{R}$ dimana $D$ merupakan himpunan terukur dan $f$ kontinu. Karena $D$ terukur, maka $D_{f}=D$ terukur.

Ambil sebarang $\alpha \in \mathbb{R}$ sehingga

$$
\begin{aligned}
\{x: f(x)>\alpha\} & =\{x: f(x) \in(\alpha, \infty)\} \\
& =f^{-1}((\alpha, \infty)) \subseteq D
\end{aligned}
$$

Interval $(\alpha, \infty)$ merupakan himpunan buka di $\mathbb{R}$, dan juga diketahui bahwa $f^{-1}((\alpha, \infty))$ merupakan himpunan buka di $D$. Karena

$$
f^{-1}((\alpha, \infty))=\bigcup_{k}\left(a_{k}, b_{k}\right)
$$

dan setiap interval merupakan himpunan terukur maka $\{x: f(x)>\alpha\}$ terukur.

Selanjutnya, kekontinuan dalam himpunan tertutup di $\mathbb{R}$ juga memiliki sifat yang hampir sama dengan kekontinuan dalam fungsi terukur secara umum. Hal ini dapat dilihat pada proposisi berikut.

\section{Proposisi 4:}

Misalkan $F$ adalah himpunan tertutup di $\mathbb{R}$. Jika $f$ adalah fungsi kontinu bernilai ril pada $E$, maka $f$ memiliki perluasan kontinu ke $\mathbb{R}$, ini berarti terdapat fungsi kontinu berniai ril $g$ pada $\mathbb{R}$ sedemikian sehingga $g=f$ pada $\mathbb{R}$.

\section{Bukti:}

Misalkan $G=F^{c}$. Kemudian $G$ adalah himpunan buka di $\mathbb{R}$ sehingga $G=\bigcup_{k \in \mathbb{N}} I_{k}$ dimana $\left(I_{k}: k \in \mathbb{N}\right)$ adalah koleksi terhitung dari interval buka saling asing di $\mathbb{R}$. Misalkan $I_{k}=$ $\left(a_{k}, b_{k}\right)$ untuk $k \in \mathbb{N}$. Misalkan didefinisikan fungsi bernilai ril $g$ pada $\mathbb{R}$ dengan $g=f$ pada $F$ dan

$$
g(x)=\frac{f\left(b_{k}\right)-f\left(a_{k}\right)}{b_{k}-a_{k}}\left(x-a_{k}\right)+f\left(a_{k}\right)
$$

untuk $x \in\left[a_{k}, b_{k}\right]$ untuk $k \in \mathbb{N}$

Ini berarti $g$ linear pada interval tutup $\left[a_{k}, b_{k}\right] \supset I_{k}$. Perlu dicatat bahwa $a_{k}$ dan $b_{k}$ di $F$, sehingga $f\left(a_{k}\right)$ dan $f\left(b_{k}\right)$ terdefinisi dan $g\left(a_{k}\right)=f\left(a_{k}\right)$ dan $g\left(b_{k}\right)=f\left(b_{k}\right)$. Misal ditunjukkan bahwa $g$ kontinu di setiap $x_{0} \in \mathbb{R}$. Sekarang $G \cap F=\varnothing$ dan $G \cup F=\mathbb{R}$ dan setiap $x_{0} \in \mathbb{R}$ adalah salah satu di $G$ atau di $F$.

Selanjutnya, pembahasan mengenai kekontinuan dalam ruang terukur juga dapat dilihat pada teorema berikut.

\section{Teorema 5 (Lusin):}

Misalkan $f$ suatu fungsi terukur $\mathfrak{M}_{L}$ bernilai ril diperluas pada $\mathbb{R}$ yang bernilai ril di mana-mana pada $\mathbb{R}$. Maka untuk setiap $\varepsilon>0$ terdapat himpunan buka $G$ di $\mathbb{R}$ dengan $\mu_{L}(G)<$ $\varepsilon$ dan fungsi $g$ bernilai ril kontinu pada $\mathbb{R}$ sedemikian sehingga $g=f$ pada $\mathbb{R} \backslash G$.

\section{Bukti:}

Ambil $\varepsilon>0$, untuk setiap $n \in \mathbb{N}$ terdapat subset $E_{n}$ dari $\mathbb{R}$ terukur $\mathfrak{M}_{L}$ dengan $\mu_{L}\left(E_{n}\right)<$ $\frac{\varepsilon}{2} \frac{1}{2^{n}}$ dan fungsi bernilai ril $f_{n}$ pada $\mathbb{R}$ sedemikian sehingga $\left|f_{n}-f\right|<\frac{\varepsilon}{2} \frac{1}{2^{n}}$ pada $\mathbb{R} \backslash E_{n}$. Misalkan $E=\cup_{n \in \mathbb{N}} E_{n}$ maka dipunyai

$$
\left|f_{n}-f\right|<\frac{\varepsilon}{2} \frac{1}{2^{n}} \text { pada } \mathbb{R} \backslash E \text { untuk setiap }
$$
$n \in \mathbb{N}$.

Ini menunjukkan bahwa barisan $\left(f_{n}: n \in\right.$ $\mathbb{N}$ ) dari fungsi kontinu konvergen seragam ke $f$ pada $\mathbb{R} \backslash E$. Kekontinuan dari $f_{n}$ dan kekonvergenan seragam $f_{n}$ ke $f$ pada $\mathbb{R} \backslash E$ mengimplikasikan bahwa $f$ kontinu pada $\mathbb{R} \backslash E$. Sekarang

$$
\begin{gathered}
\mu_{L}(E)=\mu_{L}\left(\bigcup_{n \in \mathbb{N}} E_{n}\right) \leq \sum_{n \in \mathbb{N}} \mu_{L}\left(E_{n}\right) \\
<\sum_{n \in \mathbb{N}} \frac{\varepsilon}{2} \frac{1}{2^{n}}=\frac{\varepsilon}{2}
\end{gathered}
$$

Berdasarkan ukuran luar, terdapat himpunan buka $G$ di $\mathbb{R}$ sedemikian sehingga $G \supset$ 
$E$ dan $\mu_{L}(G) \leq \mu_{L}(E)+\frac{\varepsilon}{2}<\varepsilon$. Telah diketahui bahwa $f$ kontinu pada $\mathbb{R} \backslash E$, berarti kontinu pada himpunan tertutup $\mathbb{R} \backslash G$ maka terdapat fungsi kontinu bernilai ril $g$ pada $\mathbb{R}$ sedemikian sehingga $g=f$ pada $\mathbb{R} \backslash G$.

\section{Barisan fungsi terukur dan kekonvergenan dalam ukuran}

Barisan fungsi terukur merupakan suatu barisan dimana elemen-elemennya merupakan fungsi terukur. Sifat-sifat barisan fungsi terukur meliputi limit dan supremum dari barisan merupakan fungsi terukur. Lebih jelasnya ditunjukkan oleh teorema berikut.

\section{Teorema 8[1]}

Misalkan $\left(f_{n}\right)$ barisan fungsi terukur, maka $\sup \left\{f_{1}, f_{2}, f_{3}, \ldots, f_{n}\right\}$, inf $\left\{f_{1}, f_{2}, f_{3}, \ldots, f_{n}\right\}$, $\sup _{\mathrm{n}}\left\{f_{n}\right\}, \inf _{\mathrm{n}}\left\{f_{n}\right\}, \overline{\lim }\left\{f_{n}\right\}$, dan $\underline{\lim }\left\{f_{n}\right\}$ adalah fungsi-fungsi terukur.

\section{Bukti:}

Misalkan $h$ terdefinisi dengan $h(x)=$ $\sup \left\{f_{1}(x), \ldots, f_{n}(x)\right\}$, maka

$$
\{x: f(x)>\alpha\}=\bigcup_{i=1}^{n}\left\{x: f_{i}(x)>\alpha\right\}
$$

Oleh karena itu ukuran dari $f_{i}$ mengimplikasikan pada $h$. Serupa dengan sebelumnya, jika $g$ terdefinisi dengan $g(x)=\sup _{n}(x)$, maka

$$
\{x: g(x)>\alpha\}=\bigcup_{i=1}^{\infty}\left\{x: f_{n}(x)>\alpha\right\}
$$

Sehingga $g$ terukur. Argumen serupa juga berlaku pada pernyataan mengenai infimum. Menurut pernyataan $\overline{\lim } f_{n}=$ $\inf _{n} \sup _{k} f_{k}$ diketahui bahwa $\overline{\lim } f_{n}$ terukur. Pembuktian untuk $\underline{\lim } f_{n}$ serupa.

Kekonvergenan dalam ruang terukur dapat dinyatakan bahwa limitnya ketika $n$ mentdekati tak hingga dalam ukuran bernilai 0 , yang didefinisikan sebagai berikut.

\section{Definisi 9:}

Diberikan ruang terukur $(X, \mathfrak{A}, \mu)$. Misalkan $\left(f_{n}: n \in \mathbb{N}\right)$ adalah barisan fungsi terukur- $\mathfrak{A}$ bernilai ril diperluas monoton pada himpunan $\quad D \in \mathfrak{A} . \quad\left(f_{n}: n \in \mathbb{N}\right)$ dikatakan konvergen dalam ukuran $\mu$ pada $D$ jika terdapat fungsi terukur- $\mathfrak{A}$ bernilai ril diperluas $f$ pada $D$ sedemikian hingga untuk setiap $\varepsilon>0$ berlaku $\lim _{n \rightarrow \infty} \mu\left\{D:\left|f_{n}-f\right| \geq \varepsilon\right\}=0$

Ini berarti untuk setiap $\varepsilon>0$ dan $\eta>0$ terdapat $N_{\varepsilon, \eta} \in \mathbb{N}$ sedemikian hingga

$$
\mu\left\{D:\left|f_{n}-f\right| \geq \varepsilon\right\}<\eta \text { untuk } n \geq N_{\varepsilon, \eta}
$$

Kekonvergenan ini dapat ditulis $f_{n} \stackrel{\mu}{\rightarrow} f$ pada $D$.

\section{Proposisi 10:}

Diberikan ruang terukur $(X, \mathfrak{A}, \mu)$. Misalkan $\left(f_{n}: n \in \mathbb{N}\right)$ adalah barisan fungsi terukur- $\mathfrak{U}$ bernilai ril diperluas monoton pada himpunan $D \in \mathfrak{A}$ dan misalkan $f$ adalah fungsi terukur- $\mathfrak{A}$ bernilai ril pada $D$. Maka $f_{n} \stackrel{\mu}{\rightarrow} f$ pada $D$ jika dan hanya jika untuk setiap $\delta>0$ terdapat $N_{\delta} \in \mathbb{N}$ sedemikian hingga

$\mu\left\{D:\left|f_{n}-f\right| \geq \delta\right\}<\delta$ untuk $n \geq N_{\delta}$

Bukti:

Misalkan ditunjukkan bahwa (3) ekuivalen pada pernyataan (2) pada definisi 9 dan (2) berimplikasi pada (3). Kemudian (3) berimplikasi pada (2) ditunjukkan dengan memisalkan $\varepsilon>0$ dan $\eta>0$ dan misalkan $\delta=$ $\varepsilon<\eta$. Dengan pernyataan (3) terdapat $N_{\delta} \in \mathbb{N}$ sedemikian sehingga $\mu\left\{D:\left|f_{n}-f\right| \geq \delta\right\}<$ $\delta$ untuk $n \geq N_{\delta}$. Sekarang untuk $\varepsilon \geq \delta$ berimplikasi $\left\{D:\left|f_{n}-f\right| \geq \varepsilon\right\} \subset\left\{D:\left|f_{n}-f\right| \geq\right.$ $\delta\}$ dan dipunyai

$$
\begin{gathered}
\mu\left\{D:\left|f_{n}-f\right| \geq \varepsilon\right\} \leq \mu\left\{D:\left|f_{n}-f\right| \geq \delta\right\}<\delta \\
\leq \eta \text { untuk } n \geq N_{\delta}
\end{gathered}
$$

Ini menunjukkan bahwa (3) berimplikasi pada (2).

\section{Akibat 11:}

Diberikan ruang terukur $(X, \mathfrak{A}, \mu)$. Misalkan $\left(f_{n}: n \in \mathbb{N}\right)$ adalah barisan fungsi terukur- $\mathfrak{A}$ bernilai ril diperluas monoton pada himpunan $D \in \mathfrak{A}$ dan misalkan $f$ adalah fungsi terukur- $\mathfrak{A}$ bernilai ril pada $D$. Terdapat dua barisan bilangan positif $\left(\alpha_{n}: n \in \mathbb{N}\right)$ dan $\left(\beta_{n}: n \in \mathbb{N}\right)$ sedemikian hingga

(1) $\lim _{n \rightarrow \infty} \alpha_{n}=0$ dan $\lim _{n \rightarrow \infty} \beta_{n}=0$

(2) $\mu\left\{D:\left|f_{n}-f\right| \geq \alpha_{n}\right\}<\beta_{n}$ untuk setiap $n \in$ $\mathbb{N}$

Maka $\left(f_{n}: n \in \mathbb{N}\right)$ konvergen ke $f$ di $D$ dalam ukuran $\mu$.

\section{Bukti:}

Diberikan sebarang $\varepsilon>0$ misalkan $N \in$ $\mathbb{N}$ bernilai besar sehingga untuk setiap $n>N$ 
dipunyai $\alpha_{n}<\varepsilon$ dan $\beta_{n}<\varepsilon$. Maka $\mu\left\{D: \mid f_{n}-\right.$ $f \mid \geq \varepsilon\} \subset \mu\left\{D:\left|f_{n}-f\right| \geq \alpha_{n}\right\} \quad$ sehingga $\mu\left\{D:\left|f_{n}-f\right| \geq \varepsilon\right\} \leq \mu\left\{D:\left|f_{n}-f\right| \geq \alpha_{n}\right\}<$ $\beta_{n}<\varepsilon$ untuk $n>N$. Ini menunjukkan bahwa $\left(f_{n}: n \in \mathbb{N}\right)$ konvergen ke $f$ pada $D$ dalam ukuran $\mu$ sesuai dengan proposisi 10

\section{Lemma12:}

Diberikan ruang terukur $(X, \mathfrak{A}, \mu)$. Misalkan $f$ dan $g$ adalah dua fungsi terukur- $\mathfrak{A}$ bernilai ril pada himpunan $D \in \mathfrak{A}$. Misalkan $\varepsilon$, $\varepsilon_{1}$, dan $\varepsilon_{2}$ adalah bilangan positif sedemikian hingga $\varepsilon=\varepsilon_{1}+\varepsilon_{2}$. Maka untuk suatu fungsi $h$ terukur- $\mathfrak{A}$ bernilai ril diperluas pada $D$, berlaku $\{D:|f-g| \geq \epsilon\} \subset\left\{D:|f-h| \geq \epsilon_{1}\right\} \cup$ $\left\{D:|h-g| \geq \epsilon_{2}\right\}$,

Dan $\mu\{D:|f-g| \geq \epsilon\} \leq \mu\left\{D:|f-h| \geq \epsilon_{1}\right\}+$ $\mu\left\{D:|h-g| \geq \epsilon_{2}\right\}$.

Bukti:

Misalkan tiga himpunan di (1) dapat ditulis dengan $A, A_{1}$, dan $A_{2}$. Jika $x \in D$ dan $x \notin$ $A_{1} \cup A_{2}$, maka $x \notin A_{1}$ dan $x \notin A_{2}$ sehingga $|f(x)-h(x)|<\varepsilon_{1} \quad$ dan $\quad|h(x)-g(x)|<\varepsilon_{2}$ maka

$$
\begin{aligned}
|f(x)-g(x)| & \leq|f(x)-h(x)| \\
& +|h(x)-g(x)|<\varepsilon_{1}+\varepsilon_{2}=\varepsilon
\end{aligned}
$$

Sehingga $x \notin A$. Jika $x \in D \backslash A_{1} \cup A_{2}$ maka $x \in$ $D \backslash A$. Ini menunjukkan bahwa $D \backslash A_{1} \cup A_{2} \subset$ $D \backslash A$ sehingga $A_{1} \cup A_{2} \supset A$. Ini membuktikan pernyataan (1). Maka pernyataan (2) dibuktikan dengan mengikuti pernyataan (1) dengan kemonotonan dan subaditifitas dari $\mu$.

Teorema 13 (H. Lebesgue):

Diberikan ruang terukur $(X, \mathfrak{A}, \mu)$. Misalkan $\left(f_{n}: n \in \mathbb{N}\right)$ adalah barisan fungsi terukur- $\mathfrak{A}$ bernilai ril diperluas pada himpunan $D \in \mathfrak{U}$ dan misalkan $f$ adalah fungsi terukur- $\mathfrak{A}$ bernilai ril pada $D$. Berlaku

(1) $\left(f_{n}: n \in \mathbb{N}\right)$ konvergen ke $f$ diman-mana pada himpunan $D$,

(2) $\mu\{D\}<\infty$

Maka $\left(f_{n}: n \in \mathbb{N}\right)$ konvergen ke $f$ dalam ukuran $\mu$ pada himpunan $D$.

\section{Bukti:}

Dalam ruang terukur $(X, \mathfrak{A}, \mu)$, diketahui bahwa fungsi terukur- $\mathfrak{A}$ bernilai ril diperluas pada himpunan $D \in \mathfrak{A}$ konvergen ke $f$ dimanamana pada $D$ dan $\mu(D)<\infty$ yang berimplikasi bahwa untuk setiap $m \in \mathbb{N}$ dipunyai $\lim _{n \rightarrow \infty} \mu\left\{D:\left|f_{n}-f\right| \geq \frac{1}{m}\right\}=0$. Sehingga ini menunjukkan kekonvergenan $\left(f_{n}: n \in \mathbb{N}\right)$ ke $f$ pada ukuran.

\section{Barisan Cauchy dalam Kekonvergenan terukur}

Barisan Cauchy merupakan merupakan barisan yang kekonvergenannya ditinjau dari selisih antar suku barisan. Dibagian ini akan dijelaskan barisan Cauchy dan kekonvergenannya dalam ruang ukuran.

\section{Definisi 14:}

Diberikan ruang terukur $(X, \mathfrak{A}, \mu)$. Misalkan $\left(f_{n}: n \in \mathbb{N}\right)$ adalah barisan fungsi terukur- $\mathfrak{A}$ bernilai ril pada himpunan $D \in \mathfrak{U}$. Dapat dikatakan barisan adalah barisan Cauchy yang konvergen dalam ukuran $\mu$ pada $D$ jika untuk setiap $\varepsilon>0$ dan $\eta>0$ terdapat $N_{\varepsilon, \eta} \in \mathbb{N}$ sedemikian hingga

$\mu\left\{x \in D:\left|f_{m}(x)-f_{n}(x)\right| \geq \varepsilon\right\}<\eta \quad$ untuk $m, n \geq N_{\varepsilon, \eta}$,

Atau ekuivalen dengan untuk setia $\delta>0$ terdapat $N_{\delta} \in \mathbb{N}$ sedemikian hingga

$\mu\left\{x \in D:\left|f_{m}(x)-f_{n}(x)\right| \geq \delta\right\}<\delta \quad$ untuk $m, n \geq N_{\varepsilon, \eta}$.

\section{Observasi 15:}

Jika $\left(f_{n}: n \in \mathbb{N}\right)$ adalah barisan fungsi terukur- $\mathfrak{A}$ bernilai ril dan jika $f_{n} \stackrel{\mu}{\rightarrow} f$ pada $D$, maka $\left(f_{n}: n \in \mathbb{N}\right)$ adalah barisan Cauchy yang konvergen dalam ukuran $\mu$ pada $D$.

\section{Bukti:}

Jika $f_{n} \stackrel{\mu}{\rightarrow} f$ pada $D$, maka untuk setiap $\varepsilon>0$ terdapat $N_{\varepsilon}>0$ sedemikian sehingga $\mu\left\{D:\left|f_{m}-f_{n}\right| \geq \varepsilon\right\} \leq \mu\left\{D:\left|f_{m}-f\right| \geq \frac{\varepsilon}{2}\right\}+$ $\mu\left\{D:\left|f_{n}-f\right| \geq \frac{\varepsilon}{2}\right\}<\frac{\varepsilon}{2}+\frac{\varepsilon}{2}=\varepsilon$ untuk $m, n \geq$ $N_{\varepsilon}$.

Ini menunjukkan bahwa $\left(f_{n}: n \in \mathbb{N}\right)$ adalah barisan Cauchy yang konvergen dalam ukuran $\mu$ pada $D$.

\section{Tiga prinsip Littlewood}

Dalam teori fungsi varibel ril, J.E. Littlewood menyatakan tiga prinsip yang lazim digunakan, yaitu: 
a. Hampir setiap himpunan terukur merupakan gabungan berhingga selang-selang

b. Hampir setiap fungsi terukur merupakan fungsi kontinu

c. Hampir setiap barisan fungsi (terukur) yang konvergen adalah konvergen seragam.

\section{METODOLOGI}

Penelitian ini merupakan kajian teori mengenai kekonvergenan barisan fungsi terukur, dimana akan dibuktikan bahwa fungsi terukur yang konvergen adalah konvergen seragam sesuai dengan prinsip ketiga Littlewood. Prosedur dari penenlitian ini yaitu: pertama, menganalisis sifat fungsi terukur khususnya dalam kekontinuan fungsi. Selanjutnya, menganalisis kekonvergenan barisan fungsi terukur berdasarkan sifat kontinu yang dimilikinya. Kemudian yang terakhir adalah membuktikan bahwa hampir setiap barisan fungsi terukur yang konvergen adalah konvergen seragam.

\section{PEMBAHASAN}

Kekontinuan dalam fungsi terukur dapat ditunjukkan pada terema berikut.

\section{Teorema 17 (Borel):}

Misalkan $f$ adalah fungsi terukur $\mathfrak{M}_{L}$ bernilai ril diperluas pada $\mathbb{R}$ yang bernilai rill pada $\mathbb{R}$. Kemudian untuk setiap $\varepsilon>0$ terdapat $E$ subset terukur $\mathfrak{M}_{L}$ dari $\mathbb{R}$ dengan $\mu_{L}(E)<\varepsilon$ dan fungsi bernilai ril kontinu $g$ pada $\mathbb{R}$ sedemikian hingga $|f-g|<\varepsilon$ pada $\mathbb{R} \backslash E$. Sehingga jika $M_{1} \leq f \leq M_{2}$ pada $\mathbb{R}$ untuk $M_{1}, M_{2} \in \mathbb{R}$ sedemikian hingga $M_{1}<M_{2}$, maka $g$ dapat dipilih bahwa $M_{1} \leq g \leq M_{2}$ pada $\mathbb{R}$.

\section{Bukti:}

Diberikan $\varepsilon>0$ terdapat subset terukur $\mathfrak{M}_{L} \quad E_{0}$ dari $\mathbb{R}$ dengan $\mu\left(E_{0}\right)<\frac{\varepsilon}{2}$ dan fungsi tangga kontinu kanan $s$ pada $\mathbb{R}$ sedemikian sehingga $|f-s|<\frac{\varepsilon}{2}$ pada $\mathbb{R} \backslash E_{0}$. Diberikan $s$ dengan $s=\sum_{n \in \mathbb{Z}} c_{n} \cdot \mathfrak{l}_{I_{n}}, \quad c_{n} \in \mathbb{R}$ untuk $n \in \mathbb{Z}$ dan $\left\{I_{n}: n \in \mathbb{Z}\right\}$ adalah koleksi saling asing dari interval terhingga dari kelas $\mathcal{J}_{c_{0}}$ dengan $\bigcup_{n \in \mathbb{Z}} I_{n}=\mathbb{R}$. Bilangan interval $I_{n}$ lebih jauh bahwa $I_{n}$ pada sisi kiri dari $I_{n+1}$ pada garis bilangan $\mathbb{R}$ untuk setiap $n \in \mathbb{Z}$. Ini dapat terjadi dengan melihat bahwa titik akhir dari interval daerah asal fungsi tangga kontinu kanan di $\mathbb{R}$ tidak memiliki titik limit di $\mathbb{R}$. Misalkan $I_{n}=$ $\left[a_{n}, a_{n+1}\right), a_{n}<a_{n+1}$ untuk $n \in \mathbb{Z}$. Himpunan $\left\{a_{n}: n \in \mathbb{Z}\right\}$ memuat semuat titik diskontinu dari fungsi tangga $s$ di $\mathbb{R}$. Sekarang untuk setiap $n \in$ $\mathbb{Z}, a_{n}$ adalah titik akhir kanan dari interval $I_{n-1}=\left[a_{n}, a_{n+1}\right)$ dan titik akhir kiri dari interval $I_{n-1}=\left[a_{n}, a_{n+1}\right)$. Didefinisikan

$$
\begin{gathered}
\delta_{n}=\frac{1}{4} \min \left\{\frac{1}{2^{|n|}} \frac{\varepsilon}{3}, \ell\left(I_{n+1}\right), \ell\left(I_{n}\right)\right\}, \\
I_{n}^{*}=\left[a_{n}+\delta_{n}, a_{n+1}-\delta_{n-1}\right] \subset I_{n} \\
J_{n}=\left[a_{n}-\delta_{n}, a_{n}+\delta_{n}\right]
\end{gathered}
$$

Maka

$\mathbb{R}=\cdots \cup J_{n-1} \cup I_{n-1}^{*} \cup J_{n} \cup I_{n}^{*} \cup J_{n+1} \cup I_{n+1}^{*} \cup \ldots$, dimana $J_{n-1}$ adalah disebelah kiri $I_{n-1}^{*}, I_{n-1}^{*}$ disebelah kiri $J_{n}, J_{n}$ disebelah kiri $I_{n}^{*}$ dan seterusnya. Didefinisikan fungsi kontinu bernilai ril $g$ pada $\mathbb{R}$ dengan $g=s$ pada $I_{n}^{*}$ dan memisalkan $g$ linear pada $J_{n}$ dengan asumsi nilai dari $s$ pada dua titik akhir $J_{n}$ untuk setiap $n \in \mathbb{Z}$. sehingga untuk $x \in I_{n}^{*}$ didefinisikan $g(x)=c_{n}$ dan untuk $x \in J_{n}$ didefinisikan $g(x)$ dengan

$$
\frac{g(x)-c_{n-1}}{x-\left(a_{n}-\delta_{n}\right)}=\frac{c_{n}-c_{n-1}}{\left(a_{n}+\delta_{n}\right)-\left(a_{n}-\delta_{n}\right)^{\prime}}
$$

Ini berarti,

$$
g(x)=\frac{c_{n}-c_{n-1}}{2 \delta_{n}}\left\{x-\left(a_{n}-\delta_{n}\right)\right\}+c_{n-1} .
$$

Misalkan $E=E_{0} \cup\left(\cup_{n \in \mathbb{Z}} J_{n}\right)$. Maka $E$ merupakan subset terukur $\mathfrak{M}_{L}$ dari $\mathbb{R}$ dengan

$$
\begin{gathered}
\mu_{L}(E) \leq \mu_{L}\left(E_{0}\right)+\sum_{n \in \mathbb{Z}} \mu_{L}\left(J_{n}\right)<\frac{\varepsilon}{2}+\sum_{n \in \mathbb{Z}} 2 \delta_{n} \\
<\frac{\varepsilon}{2}+\frac{1}{2} \sum_{n \in \mathbb{Z}} \frac{1}{2^{|n|}} \frac{\varepsilon}{3}=\varepsilon
\end{gathered}
$$

Dan $g=s$ pada $\mathbb{R} \backslash E$. Maka $|f-g| \leq \mid f-$ $s|+| s-g|=| f-s \mid<\varepsilon$ pada $\mathbb{R} \backslash E$. Jika $M_{1} \leq f \leq M_{2}$ pada $\mathbb{R}$, maka $s$ dapat dipilih sehingga $M_{1} \leq s \leq M_{2}$ pada $\mathbb{R}$. maka untuk definisi fungsi kontinu bernilai ril $g$ diatas, diperoleh $M_{1} \leq f \leq M_{2}$ pada $\mathbb{R}$.

Menurut teorema tersebut, dapat diketahui bahwa $f$ merupakan fungsi kontinu jika terdapat $g$ sedemikian sehingga $|f-g|<\varepsilon$. 
Seanjutnya, kekonvergenan dalam ruang terukur memiliki keunikan tersendiri. Khususnya fungsi suatu barisan akan konvergen yang termuat dalam teorema berikut.

\section{Teorema 18 (keunikan limit konvergen dalam ukuran):}

Diberikan ruang terukur $(X, \mathfrak{A}, \mu)$. Misalkan $\left(f_{n}: n \in \mathbb{N}\right)$ adalah fungsi terukur- $\mathfrak{A}$ bernilai ril diperluas pada himpunan $D \in \mathfrak{A}$ dan misalkan $f$ dan $g$ adalah dua fungsi terukur- $\mathfrak{A}$ bernilai ril pada himpunan $D$. Jika $f_{n} \stackrel{\mu}{\rightarrow} f$ pada $D$ dan $f_{n} \stackrel{\mu}{\rightarrow} g$ pada $D$, maka $f=g$ a.e. on $D$.

\section{Bukti:}

Andaikan $f_{n} \stackrel{\mu}{\rightarrow} f$ pada $D$ dan $f_{n} \stackrel{\mu}{\rightarrow} g$ pada $D$ juga. Maka untuk setiap $\varepsilon>0$ dipunyai

$$
\left\{\begin{array}{l}
\lim _{n \rightarrow \infty} \mu\left\{D:\left|f_{n}-f\right| \geq \varepsilon\right\}=0 \\
\lim _{n \rightarrow \infty} \mu\left\{D:\left|f_{n}-g\right| \geq \varepsilon\right\}=0
\end{array}\right.
$$

Untuk menunjukkan bahwa $f=g$ pada $D$, diasumsikan suatu kontradiksi bahwa $\mu\{D: f \neq$ $g\}>0$. Maka sejak $f(x) \neq g(x)$ jika dan hanya jika $|f(x)-g(x)|>0$, diperoleh

$$
\mu\{D:|f-g|>0\}>0
$$

Sekarang $\quad\{D:|f-g|>0\}=\bigcup_{k \in \mathbb{N}}\{D: \mid f-$ $\left.g \mid \geq \frac{1}{k}\right\}$, diperoleh

$$
\begin{aligned}
& \mu\{D:|f-g|>0\} \\
& \quad \leq \sum_{k \in \mathbb{N}} \mu\left\{D:|f-g| \geq \frac{1}{k}\right\},
\end{aligned}
$$

Dengan (2), ruas kiri dari (3) adalah positif. Maka tidak semua penjumlahan diruas kanan sama dengan 0 . Kemudian terdapat suatu $k_{0} \in \mathbb{N}$ sedemikian sehingga

$$
\mu\left\{D:|f-g| \geq \frac{1}{k_{0}}\right\}>0 .
$$

Sehingga untuk setiap $n \in \mathbb{N}$ diperoleh

$$
\begin{aligned}
\mu\{D:|f-g| & \left.\geq \frac{1}{k_{0}}\right\} \\
& \leq \mu\left\{D:\left|f-f_{n}\right| \geq \frac{1}{2 k_{0}}\right\} \\
& +\mu\left\{D:\left|f_{n}-g\right| \geq \frac{1}{2 k_{0}}\right\} .
\end{aligned}
$$

Dengan memisalkan $n \rightarrow \infty$ pada ruas kanan pertidaksamaan terakhir, diperoleh

$$
\mu\left\{D:|f-g| \geq \frac{1}{k_{0}}\right\}=0
$$

Sehingga kontradiksi dengan ketaksamaan (4) yang berarti kontradiksi dengan pengandaian.

Kekonvergenan barisan dalam ruang terukur juga berkaitan dengan kekonvergenan seragam. Suatu barisan fungsi bernilai ril diperluas $f_{n}: n \in \mathbb{N}$ konvergen seragam pada himpunan $D$ jika untuk setiap $\varepsilon>0$ yang diberikan, terdapat $N \in \mathbb{N}$ yang bergantung pada $\varepsilon$ tetapi tidak pada $x \in D$ sedemikian sehingga $\left|f_{n}(x)-f(x)\right|<\varepsilon$ untuk setiap $x \in D$ dimana $n \geq N$, atau ekuivalen dengan untuk setiap $m \in \mathbb{N}$ terdapat $N \in \mathbb{N}$ sedemikian sehingga $\left|f_{n}(x)-f(x)\right|<\frac{1}{m}$ untuk setiap $x \in D$ dimana $n \geq N$. Salah satu kelebihan dari kekonvergenan seragam yaitu kemampuannya mempertahankan kekontinuan suatu fungsi. Hal ini berarti jika suatu barisan fungsi $f_{n}$ konvergen seragam ke fungsi $f$, maka $f$ kontinu.

Setelah pembahasan mengenai kekontinuan dalam fungsi terukur dan kekonvergenan dalam ruang terukur serta memperhatikan sifat dari kekonvergenan seragam, ditunjukkan satu teorema kekonvergenan seragam yang berlaku dalam ruang terukur.

\section{Teorema 19:}

Misalkan untuk setiap $\varepsilon>0$ terdapat $E$ subset terukur $\mathfrak{M}_{L}$ dari $\mathbb{R}$ dengan $\mu_{L}(E)<\varepsilon$. Suatu barisan fungsi $f_{n}$ yang konvergen ke $f$ di $E$ dikatakan konvergen seragam jika terdapat fungsi kontinu $g$ sedemikian sehingga $|f-g|<$ $\varepsilon$ yang setara dengan $f=g$ dimana-mana.

\section{Bukti:}

Jika $f_{n}$ konvergen ke $f$ untuk $x \in D$ maka berlaku $\left|f_{n}-f\right|<\varepsilon$. Misalkan terdapat fungsi kontinu $g$ sedemikian sehingga $|f-g|<\varepsilon$. Menurut Teorema $17 \quad f$ merupakan fungsi terukur kontinu pada $D$. Karena untuk setiap $\varepsilon>$ 0 berlaku $|f-g|<\varepsilon$ maka $f-g=0$. Sehingga menurut Teorema $18 f_{n}$ konvergen ke $f\left(f_{n} \stackrel{\mu}{\rightarrow} f\right)$ dan $f_{n}$ konvergen ke $\left(f_{n} \stackrel{\mu}{\rightarrow} g\right)$. Ini menyatakan bahwa $f_{n}$ konvergen seragam ke $f$ dimana $f$ kontinu sesuai dengan sifat kekonvergenan seragam yang mempertahankan kekntinuan fungsi.

Teorema 19 membuktikan secara parsial prinsip ketiga littlewood bahwa hampir setiap barisan fungsi terukur konvergen adalah 
konvergen seragam. Dimana pada pernyataan tersebut ditunjukkan bahwa $f_{n}$ konvergen ke fungsi kontinu yang bersesuaian dengan kemampuan kekonvergenan seragam dalam mempertahankan kekontinuan fungsi.

\section{KESIMPULAN}

Kesimpulan dari tulisan ini adalah suatu barisan fungsi terukur dikatakan konvergen seragam ketika barisannya konvergen ke suatu fungsi dimana fungsi tersebut kontinu. Hal ini diketahui dari sifat kekonvergenan seragam yang mempertahankan kekontinuan fungsi.

\section{DAFTAR PUSTAKA}

[1] Goldberg, Richard R. (1976). "Method of Ril Analysis”.New York : John Wiley and Sons.

[2] Royden, H.L.(1989). "Ril Analysis $3^{\text {rd"”. }}$ New York. Macmillan Publishing Company.

[3] Ubaidillah, Firdaus, Soeparna Darmawijaya dan Ch. Rini Indrati. (2013). "Kekonvergenan Barisan didalam Ruang Fungsi Kontinu C $[a, b]$ ".Jurnal CAUCHY, Vol. 2 No. 4, halaman 184188

[4] Yeh, J..(2006). Riel Analysis: Theory of Measure and Integration $2^{\text {nd }}$. Singapore. World Scientific Publishing. 